\title{
ZIELEŃ W WARSZAWSKIM STANDARDZIE MIESZKANIOWYM
}

\author{
Beata Joanna Gawryszewska ${ }^{1 凶}$, Justyna Biernacka² \\ ${ }^{1}$ Wydział Budownictwa i Inżynierii Środowiska, Szkoła Główna Gospodarstwa Wiejskiego w Warszawie, Warszawa \\ ${ }^{2}$ Kolegium Zarządzania i Finansów, Szkoła Główna Handlowa w Warszawie, Warszawa
}

\begin{abstract}
STRESZCZENIE
Opracowany w 2018 roku przez Urząd m.st. Warszawy Warszawski Standard Mieszkaniowy wersja 1.2 (WSM 1.2) jako jeden z pięciu priorytetów w miejskich inwestycjach wymienia przyrodę, a w niej i zieleń. Ważne było więc opracowanie zapisów standardu z zastosowaniem zasad budownictwa zrównoważonego, w tym dostosowanie do potrzeb społeczności mieszkańców. Celem artykułu była weryfikacja tych zapisów na tle zaobserwowanych procesów zamieszkiwania, a także zmieniających się preferencji estetycznych mieszkańców w zakresie zarówno zieleni, jak i popularnych wskaźników ekologiczno-przestrzennych i certyfikatów zrównoważonego budownictwa. W tekście przytoczone zostały obszerne fragmenty poświęcone WSM oraz zestawienia wskaźników i wyników badań mających na celu charakterystykę współczesnych kierunków kształtowania zieleni w otoczeniu mieszkań i jej optymalizacji (m.in. swobodna wegetacja, kształtowane oddolnie ogrody). Została również szeroko omówiona obecna w opracowanym standardzie koncepcja EKOSPOTu.
\end{abstract}

Słowa kluczowe: wskaźniki ekologiczno-przestrzenne, przestrzeń społeczna, osiedle mieszkaniowe, rewitalizacja, budownictwo komunalne, EKOSPOT

\section{WSTĘP}

Jesienią 2017 roku, podczas prac nad programem warszawskiej polityki mieszkaniowej Mieszkania2030 pojawił się pomysł stworzenia Warszawskiego Standardu Mieszkaniowego, który stał się załącznikiem do programu. Powstały dokument określa kierunki rozwoju mieszkalnictwa, które mają podnieść jakość zamieszkiwania w budynkach należących do miasta zarówno w nowych inwestycjach, jak i istniejących w razie ich modernizacji. Jak czytamy w preambule: „Warszawski Standard Mieszkaniowy to ujęty w czytelnej formie zbiór zasad, zgodnie z którymi w stolicy mają powstawać mieszkania dobrej jakości. Określa oczekiwania miasta wobec przyszłych inwestorów i wychodzi naprzeciw potrzebom mieszkanek i mieszkańców" (BPL UM Warszawa, 2018). Trzeba przy tym zaznaczyć, że przygotowany dokument nie dotyczy jako takiej przestrzeni osiedla mieszkaniowego, a jedynie pojedynczego budynku, co wyłącza z niego wiele istotnych kwestii z zakresu urbanistyki i zielonej infrastruktury, które powinny być uwzględnione $\mathrm{w}$ dalszych pracach w ramach wspomnianej polityki miejskiej.

Aktualna wersja dokumentu (opatrzona numerem 1.2) została przygotowana $\mathrm{w} 2018$ roku przez grupe ekspertów działających na zlecenie Biura Polityki Lokalowej Urzędu m.st. Warszawy ${ }^{1}$. Tekst standardu został podzielony na pięć głównych rozdziałów dotyczą-

\footnotetext{
${ }^{1}$ Zespół autorski w składzie: Justyna Biernacka (koordynacja merytoryczna), Joanna Erbel (koordynacja strategii dla m.st. Warszawy „Polityka mieszkaniowa - Mieszkania2030” oraz programu operacyjnego), Sabina Augustynowicz (zarządzanie i gospodarowanie), Tomasz Duda (psychologia środowiskowa i zdrowie publiczne), Beata Joanna Gawryszewska (przyroda), Piotr Jurkiewicz (budynek i podwórko), Krystyna Krzekotowska (zagadnienia prawne do wersji 1.0), Andrzej Rajkiewicz (efektywność energetyczna).
} 
cych przygotowania inwestycji, jej lokalizacji, przyrody, a w szczególności zieleni na terenie inwestycji, problematyki związanej z projektowaniem i funkcjonowaniem samego budynku i jego najbliższego otoczenia (podwórka) oraz zarządzania i gospodarowania nieruchomością (BPL UM Warszawa, 2018). Efekt końcowy został przekazany do konsultacji społecznych w październiku 2018.

$\mathrm{W}$ prezentowanym artykule podejmujemy kwestie zieleni obecne w zapisach Warszawskiego Standardu Mieszkaniowego $1.2 \mathrm{w}$ kontekście problematyki jej jakości w przestrzeniach zamieszkiwanych oraz związanych z nią zmieniających się potrzeb i oczekiwań mieszkańców miasta. Celem przedstawionej pracy jest dyskusja zapisów dotyczących zieleni, zawartych w WSM 1.2 na tle funkcjonujących na świecie certyfikatów zrównoważonego budownictwa i wskaźników ekologiczno-przestrzennych, a także usankcjonowanej tradycją roli zieleni w strukturze osiedla społecznego.

\section{MATERIAt I METODY}

Podstawowym założeniem przyjętym w pracach nad WSM 1.2, a także zawartymi w tym tekście rozważaniami jest jego zastosowanie $\mathrm{w}$ komunalnym budownictwie wielorodzinnym zarówno pojedynczych budynków, jak i ich kompleksów. Jako poligony do weryfikacji celowości zapisów standardu posłużyły więc budynki w dwóch osiedlach domów komunalnych w Warszawie, przy ul. Kłobuckiej 14/16/18 oraz ul. Jagiellońskiej 47.

Do analizy posłużyły również wskaźniki ekologiczno-przestrzenne: Biotope Area Factor - BAF (1994, Berlin), Green Space Factor - GF (2001, Malmö), Greenery Provision - GnP (2005, Singapur), Seattle Green Factor - SGF (2007, Seattle), porównane na podstawie opracowania Wskaźniki ekologiczno-przestrzenne jako standard ksztaltowania zabudowy mieszkaniowej (Giedych, 2015), a także najnowsze edycje międzynarodowych standardów zrównoważonego budownictwa służących certyfikacji budynków: Leadership in Energy and Environmental Design - LEED (USGBC, 2019), BRE Environmental Assessment Method - BREEAM (BRE Global, 2016) i WELL Building Standard (IWBI, 2019). Jako pod- stawa dyskusji posłużyły tradycyjne zasady projektowania zieleni w osiedlu społecznym, omówione na podstawie Zasad spolecznych projektowania osiedli mieszkaniowych (Brukalska, 1947).

$\mathrm{Na}$ kolejne etapy postępowania badawczego złożyły się:

- analiza współczesnych potrzeb i oczekiwań mieszkańców w aspekcie tradycji zieleni w osiedlu społecznym oraz ogrodów społecznościowych zakładanych przez aktywistów;

- porównanie i analiza zapisów dotyczących zieleni i środowiska przyrodniczego $\mathrm{w}$ popularnych certyfikatach oraz wskaźnikach ekologiczno-przestrzennych;

- diagnoza stanu struktury i form zieleni w skróconych studiach przypadków dwóch osiedli domów komunalnych w Warszawie;

- dyskusja zapisów WSM 1.2 w zakresie zieleni.

Etapy 1 i 2 miały na celu określenie form i rodzajów zieleni postulowanych przez teorię osiedla społecznego oraz mieszkańców. Etapy 3 i 4 miały na celu weryfikację sposobów zabezpieczenia interesu mieszkańców i przyrody w zakresie zieleni w miejscu zamieszkania. Weryfikacja problemów i potrzeb przestrzennych specyficznych dla inwestycji, których ma dotyczyć standard, nastapiła w etapie 5. Pracę kończą dyskusja zapisów WSM 1.2 oraz konkluzje.

\section{ZIELEŃ JAKO NARZĘDZIE KREACJI PRZESTRZENI SPOKECZNEJ}

Idea osiedla społecznego - pokłosie międzynarodowych kongresów architektury nowoczesnej (CIAM), a w ich konsekwencji Karty Ateńskiej z 1933 roku (KNWAW ASP, 1941) - legła u podstaw współczesnego myślenia o przestrzeni zamieszkiwanej, a jej immanentną częścią była zieleń (Gawryszewska i Wilczyńska, 2016). W teorii Brukalskiej, uczestniczki IV CIAM, autorki Zasad spotecznych projektowania osiedli mieszkaniowych, projektantki pierwszego w Polsce społecznego osiedla Warszawskiej Spółdzielni Mieszkaniowej na Żoliborzu, system zieleni jest złożony z różnorodnych form: „prywatnych" ogródków w skrzynkach na parapetach okiennych, ogrodów na dziedzińcach, osiedlowych 
parków i wreszcie otwartych terenów podmiejskich (Brukalska, 1947).

Obserwując ogrody osiedla Warszawskiej Spółdzielni Mieszkaniowej na Żoliborzu po 90 latach, możemy dostrzec postulowane przez Brukalską typy zieleni będące efektem działania samych mieszkańców, którzy w procesie zamieszkiwania wypracowali strukturę przestrzenną składającą się z namiastki przestrzeni prywatnej (ogródków pod oknami mieszkań na parterze) i wspólnie kreowanej przestrzeni społecznej pośrodku dziedzińców - podwórek z bożonarodzeniowymi drzewkami, samodzielnie reperowanymi przez mieszkańców ławkami, karmnikami dla ptaków czy kotów, wspólnie pielęgnowanymi rabatami kwitnących krzewów i kwiatów (Gawryszewska i Piłko, 2004). Takie działania psychologia środowiskowa nazywa terytorialnymi, a w tym wypadku trzeba zauważyć, że odbywaja się one $\mathrm{z}$ wykorzystaniem roślin budujących wizerunek ogrodu (Lewicka, 2012; por. Gawryszewska, 2013).

Skoro taka forma i struktura zieleni osiedlowej (z minimalnym udziałem stereotypowych trawników i żywopłotów, za to z przewagą anonimowych form ogrodowych tworzących domeny prywatną i społeczną) wykształciła się w procesie zamieszkiwania, można postawić tezę, że są to forma i struktura wynikające z potrzeb mieszkańców, a zatem optymalne. Teza ta znalazła potwierdzenie $\mathrm{w}$ przeprowadzonych w latach 2007-2016 badaniach wielu innych młodszych osiedli mieszkaniowych w Warszawie: Młynowa, Bernardyńskiej, Ursynowa Północnego, Służewa. Zarówno ogródki podokienne, jak oddolnie tworzone przestrzenie społeczne nie zawsze występują $\mathrm{w}$ dojrzałej i kompletnej formie jak w żoliborskim osiedlu, ale są w nich zauważalnie obecne (Gawryszewska, 2018).

Przestrzeń społeczna jest współcześnie reprezentowana przez jeszcze jedną niewymienioną przez Brukalską wernakularną formę zieleni, jaką jest ogród społecznościowy. Ten typ pojawił się m.in. na Młynowie, Bemowie i Kabatach jako znak rozpoznawczy „krajobrazu zaangażowanego”, czyli kształtowanego oddolnie, sygnalizującego obecność dojrzałej wspólnoty mieszkańców (Gawryszewska, 2013). W słynnym osiedlu domków fińskich na Jaz- dowie ogrody społecznościowe pełne warzyw i ziół stały się zwiastunem przejęcia terenu przez organizacje pozarządowe i nowego oddolnego budowania miasta $\mathrm{w}$ warunkach gospodarki uczestniczacej. Warto też zwrócić uwagę, że produkcja żywności choć obecna w tych ogrodach, ma niewielkie znaczenie. Gromadząc społeczność wokół wspólnego celu, jakim jest uprawa, ogrody te stają się skutecznym narzędziem rewitalizacji społecznej i stymulowania postaw kreatywnych mieszkańców (Gawryszewska, 2018). Zatem i w tym przypadku takie ogrody należy przeciwstawić anonimowej „zieleni miejskiej”.

W systemie zieleni opisywanym przez Brukalską znajdują się tereny otwarte, lasy miejskie i zieleń przedwojennych przedmieść warszawskich Bielan. Przestrzenie takie pojawiają się dziś w różnorakich standardach dostępności zieleni. Dość przywołać angielski Accessible Natural Greenspace Standard - ANGSt (English Nature, 2014), który postuluje obecność przynajmniej 2 ha powierzchni „naturalnego” terenu w izochronie $5 \mathrm{~min}(300 \mathrm{~m})$ od domu. Dziś dostępność takich terenów stale się zmniejsza, za to często są one zastępowane przez ,nieużytki” pokryte zbiorowiskami „czwartej natury”, czyli swobodnie wegetująca mieszanką roślin rodzimych i nierodzimych, często synantropijnych i ruderalnych (Kowarik, 2011; Del Tredici, 2014). Badania 25 takich obszarów w Warszawie w latach 2016-2018 zaowocowały konkluzja, że są one w strukturze zieleni osiedlowej równie ważne jak prywatne ogródki i przestrzenie społeczne oraz ogrody społecznościowe. Pytani o preferowane formy zieleni mieszkańcy wskazują jedne i drugie jako istotne. Pierwsze służą realizacji potrzeby terytorialności, drugie codziennej rekreacji - spacerom z psem, joggingowi, wycieczkom rowerowym (Gawryszewska, Ciszewska, Łepkowski, Nejman i Wilczyńska, 2018). Warta zauważenia jest również zmiana preferencji estetyki zieleni. Charakterystyczna dla terenów „nieużytków" miejskich swobodna wegetacja jest kojarzona $\mathrm{z}$ różnorodnością biologiczną, a zatem $\mathrm{z}$ dużą wartością przyrodniczą, biofilią i bezpieczeństwem przyrodniczym (Wilson, 2009). Estetyka nieużytku stała się w oczach mieszkańców estetyką natury, autentyczną i racjonalizowaną jako właściwą (Gawryszewska, Łepkowski i Wilczyńska, 2019). 


\section{JAKOŚĆ ZIELENI W CERTYFIKATACH I WSKAŹNIKACH EKOLOGICZNO- -PRZESTRZENNYCH}

Wielokryterialne systemy oceny budynków powszechnie nazywane standardami lub certyfikatami zielonego budownictwa służą do określenia wpływu obiektu na trzy obszary: środowiskowy, społeczny oraz ekonomiczny. Te kwestie znajdują odzwierciedlenie w doborze kryteriów, które dla większości certyfikacji są zbieżne i dotyczą takich obszarów, jak: zarządzanie budową i inwestycją, teren i lokalizacja inwestycji, mobilność, efektywność w zakresie zużycia zasobów naturalnych, dobór materiałów budowlanych i jakość środowiska wewnętrznego budynku. Najbardziej popularnymi na świecie systemami są: Building Research Establishment Environmental Assessment Method (BREEAM) analizowany w wersji International New Construction i opracowany przez brytyjską organizację Building Research Establishment) w 1990 roku (BRE Global, 2016) oraz LEED w wersji 4.1 Residential BD+C Multifamily Homes Core and Shell z kwietnia 2019 r. (USGBC, 2019), który jest amerykańskim systemem opracowanym przez Green Building Council w 1998 roku (USGBC, 2019). Wraz z rozwojem idei zielonych certyfikacji stworzono uzupełniający system oceny budynków WELL (wersja 2.0 z 2019 r.; IWBI, 2019), opracowany przez International WELL Building Institute z 2007 roku, który rozwija i uszczegóławia zagadnienia wpływu budynku na zdrowie i jakość życia użytkowników (Biernacka, 2016). Zagadnienia związane ze środowiskiem przyrodniczym pojawiają się we wszystkich wspomnianych systemach, wzbogacane i rozwijane $\mathrm{w}$ ich kolejnych wersjach. $\mathrm{W}$ tabeli przedstawiono zestawienie zawartych $\mathrm{w}$ nich treści i kryteriów związanych z przyrodą rozumianą jako zieleń budynkowa i w otoczeniu obiektu.

Istotną kwestią jest również zasadność stosowania wskaźników ekologiczno-przestrzennych, których zadaniem jest zabezpieczenie odpowiedniej powierzchni i jakości powierzchni przyrodniczo aktywnych na terenie inwestycji. Słabością stosowanego w Polsce wskaźnika powierzchni biologicznie czynnej (PBC) jest to, że uwzględnia jedynie powierzchnię, można kolokwialnie powiedzieć jest „dwuwymiarowy”. Poszukując bardziej ,,przestrzennej” formy opisu preferowanej jakości zieleni towarzyszącej zamieszkiwaniu,

Tabela. Zestawienie wymagań dotyczących zagadnień krajobrazowych i przyrodniczych w certyfikacjach LEED, BREEAM i WELL (opracowanie własne)

Table. List of requirements regarding landscape and natural issues in LEED, BREEAM and WELL certificates (authors own work)

System, obszar działań, numer i tytuł wymagania System, activity, area, requirement number and title

Cel, wymagania

Aim, requirements
Wymagania dotyczące kwestii krajobrazowych i przyrodniczych

Requirements addressing landscape and nature issues

\begin{tabular}{|c|c|c|}
\hline & \\
\hline $\begin{array}{l}\text { LEED } \\
\text { Integrative Process (IP1) }\end{array}$ & $\begin{array}{l}\text { Doprowadzenie do wczesnej analizy wzajem- } \\
\text { nych powiązań systemów budynkowych oraz } \\
\text { przeszkolenie wykonawców instalacji w za- } \\
\text { kresie energooszczędności w celu podniesie- } \\
\text { nia ich wydajności i efektywności. }\end{array}$ & $\begin{array}{l}\text { Przeprowadzenie uproszczonego modelowania } \\
\text { energetycznego bryły budynku w celu ziden- } \\
\text { tyfikowania szans na redukcję zużycia energii } \\
\text { z uwzględnieniem analizy warunków loka- } \\
\text { lizacyjnych, w tym: zacienienia, dostępu do } \\
\text { światła dziennego oraz ukształtowania terenu } \\
\text { i krajobrazu. }\end{array}$ \\
\hline BREEAM & nie dotyczy & nie dotyczy \\
\hline $\begin{array}{l}\text { WELL } \\
\text { Community (C02) }\end{array}$ & $\begin{array}{l}\text { Tworzenie zintegrowanej społeczności po- } \\
\text { przez zapewnienie równości społecznej, zaan- } \\
\text { gażowania obywatelskiego i dostępności. }\end{array}$ & $\begin{array}{l}\text { Wspieranie projektowania z udziałem przy- } \\
\text { szłych użytkowników poprzez przeprowadze- } \\
\text { nie procesu konsultacyjnego zgodnie z wytycz- } \\
\text { nymi. }\end{array}$ \\
\hline
\end{tabular}


Tabela - cd. / Table - continue

System, obszar działań, numer i tytuł wymagania System, activity, area, requirement number and title

LEED

Location and Transportation (LT2)

Sensitive Land Protection

BREEAM

Land Use and Ecology (LE01)

Site Selection

WELL

LEED

Sustainable Sites (SS1)

Site Assessment (SS2)

Protect or Restore Habitat

\section{BREEAM}

Land Use and Ecology

(LE03)

Ecological value of site and protection of ecological features (LE 04)

Enhancing Site Ecology (LE05)

Long Term Impact on Biodiversity

WELL
Cel, wymagania

Aim, requirements
Wymagania dotyczące kwestii krajobrazowych i przyrodniczych

Requirements addressing landscape and nature issues
Unikanie zabudowy terenów wrażliwych pod względem środowiskowym oraz redukcja negatywnego wpływu na środowisko wynikającego ze zlokalizowania budynku na takim terenie.

Promowanie zrównoważonego użytkowania gruntów, ochrony i tworzenia siedlisk oraz poprawy długoterminowej różnorodności biologicznej na terenie zabudowywanym, ponownego wykorzystania terenów poprzemysłowych lub terenów o małej wartości ekologicznej oraz długoterminowego zarządzania różnorodnością biologiczną.

nie dotyczy

Zachowanie istniejących obszarów naturalnych i przywrócenie bioróżnorodności na obszarach wcześniej przekształconych i zdegradowanych środowiskowo.

Zachęcanie do rozwoju terenów, których obecna wartość ekologiczna jest już niewiel$\mathrm{ka}$, ochrony istniejących cech ekologicznych przed poważnymi szkodami podczas prac budowlanych oraz zwiększenia wartości ekologicznej obiektu i minimalizacji jego negatywnego wpływu na środowisko przyrodnicze.

Wymagania dotyczą lokalizacji budynku na terenie już wcześniej zabudowanym lub na terenie, który nie jest: terenem rolnym, obszarem zalewowym, terenem bytowania gatunków zagrożonych wyginięciem, mokradłem, nabrzeżem lub terenem zlokalizowanym do $30 \mathrm{~m}$ od akwenu.

Wymagania dotyczą wykorzystania terenów już wcześniej zabudowanych, przywracania ich do użytkowania oraz unikania zabudowania terenów niepoddawanych wcześniej antropopresji.

nie dotyczy

Wymagania dotyczą przeprowadzenia oceny terenu przed przystapieniem do projektowania, rozważenia różnych opcji zrównoważonego rozwoju obszaru i podsumowania podjętych w procesie projektowym decyzji. Ocena terenu powinna uwzględniać zagadnienia topograficzne, hydrologiczne, klimatyczne, wegetacji i zasobów gruntowych. W zakresie ochrony i odtworzenia habitatu wymagania dotyczą zachowania i zabezpieczenia przed wszelkimi działaniami budowlanymi $40 \%$ terenów zieleni na terenie budowy oraz wykorzystania rodzimej lub zaadaptowanej roślinności w celu przywrócenia bioróżnorodności na co najmniej $25 \%$ wcześniej przekształconego terenu.

Wymagania dotyczą oceny wartości ekologicznej terenu oraz ochrony i zachowania jego istniejących cech ekologicznych ze szczególnym uwzględnieniem lasów i pojedynczo rosnących drzew, źródeł, rzek i akwenów, mokradeł, łąk, zarośli, terenów pustynnych i innych obszarów wartościowych ekologicznie, a także siedlisk zwierząt w opuszczonych budynkach. Dodatkowe wymagania dotyczą wdrożenia rekomendacji opracowanych przez ekologa, zwiększających wartość ekologiczną terenu oraz opracowania planu zarządzania i rozwoju bioróżnorodności w trakcie użytkowania budynku.

nie dotyczy 
Tabela - cd. / Table - continue

\begin{tabular}{lcc}
\hline System, obszar działań, & Cel, wymagania & Wymagania dotyczace kwestii krajobrazowych \\
numer i tytuł wymagania & i przyrodniczych \\
$\begin{array}{l}\text { System, activity, area, } \\
\text { requirement number and title }\end{array}$ & Aim, requirements & Requirements addressing landscape \\
and nature issues
\end{tabular}

Zapewnienie przestrzeni zewnętrznej większej lub równej 30\% całkowitej powierzchni obiektu (w tym powierzchni budynku). $25 \%$ wymaganego minimum $30 \%$ całkowitej przestrzeni na zewnątrz musi być obsadzone dwoma lub więcej

LEED

Sustainable Sites (SS3)

Open Space

BREEAM

nie dotyczy

WELL

Mind (M07)

Regenerative Spaces stresie.
Wykreowanie zewnętrznej otwartej przestrzeni zachęcającej do interakcji ze środowiskiem przyrodniczym, interakcji społecznych, biernej rekreacji i aktywności fizycznej.

Wykreowanie przestrzeni na zewnątrz i wewnątrz budynku, które umożliwiają regenerację $\mathrm{i}$ ulgę $\mathrm{w}$ zmęczeniu psychicznym lub rodzajami roślinności lub mieć „,nad głową” wegetatywny baldachim. Warunek jest spełniony poprzez zapewnienie dostępu do ogólnodostępnej lub otwartej przestrzeni społecznościowej o powierzchni co najmniej 0,4 ha, zlokalizowanej w odległości do $800 \mathrm{~m}$ poza terenem inwestycji. Wymagania dotyczące otwartej przestrzeni można spełnić za pomocą jednej dużej otwartej przestrzeni lub dwóch mniejszych pomieszczeń o łącznej powierzchni 3/4 akrów (0,3 ha).

nie dotyczy

Zapewnienia dostępu do zewnętrznej przestrzeni regeneracji dla wszystkich mieszkańców budynku (min. powierzchnia $7 \mathrm{~m}^{2}$ na mieszkańca). Przestrzeń ta ma być stale utrzymywana w czystości i może składać się z kilku mniejszych. Zaprojektowana wyłącznie do kontemplacji, relaksu i regeneracji, dostępna dla osób z niepełnosprawnościami, wygłuszone na irytujące dźwięki, wyposażona w obiekty wytwarzające naturalny szmer (szemrząca woda, szum wiatru), zapewnia komfort temperaturowy dzięki obszarom zacienionym i nasłonecznionym, gwarantuje urozmaicenie miejsc do siedzenia i leżenia, wprowadza elementy natury, wizualną prywatność oraz uspakajające kolory, tekstury i formy.

Zapewnienie zacienienia lub nieabsorbującej ciepło powierzchni dla $50-75 \%$ powierzchni utwardzonych poprzez wprowadzenie: dachów zielonych, zacienienia z wykorzystaniem dojrzałej roślinności (drzew, krzewów) lub konstrukcji obrośniętych roślinami (pergole, zadaszenia).

nie dotyczy

nie dotyczy eksperci powołują się na wskaźniki używane na świecie (Szulczewska, Giedych i Solarek, 2015). Giedych (2015) porównuje ze sobą Biotope Area Factor - BAF
(Berlin), Green Space Factor - GF (Malmö), Greenery Provision - GnP (Singapur) oraz Seattle Green Factor - SGF. W zestawieniach powierzchni pokrytych 
zielenią powtarzają się: zieleń na gruncie rodzimym, zieleń na powierzchniach architektonicznych, w tym zastosowanie pnączy, naturalna wegetacja roślin, ogrody mieszkańców, produkcja żywności, a nawet widoczność ogrodu z sąsiednich terenów publicznych. Wskaźniki zwracają też uwagę na minimalizację areału nawierzchni nieprzepuszczalnych na korzyść obszarów infiltracji wód opadowych i bioretencji.

Interesującym stosowanym podejściem jest waloryzacja zieleni za pomocą wskaźnika pokrycia liśćmi (Leaf Area Index - LAI, uwzględniony w singapurskim standardzie GnP) oraz wskaźnika pokrycia rzutami koron drzew (Canopy Tree Index - CTI). W badaniach Maco i McPhersona (1999) CTI w obszarach zamieszkiwanych z dojrzałym drzewostanem wynosi $50 \%$, a w przestrzeniach publicznych ulic i chodników $25 \%$. Po odpowiedniej weryfikacji CTI wydaje się być wygodnym wskaźnikiem do zastosowania dla projektantów przestrzeni towarzyszących budynkom mieszkalnym.

\section{ZIELEŃ PRZY WARSZAWSKICH BUDYNKACH KOMUNALNYCH}

Wiosną 2018 roku autorzy standardu dokonali wizji lokalnej w dwóch niedawno zbudowanych warszawskich osiedlach mieszkań komunalnych: przy ul. Kłobuckiej 14/16/18 na Zielonym Ursynowie i przy ul. Jagiellońskiej 47 na Pradze Północ. Miała ona na celu weryfikację, czy zalecenia standardu dotyczących m.in. zieleni można tam zastosować. Ważna była możliwość wprowadzenia zieleni na powierzchniach architektonicznych i zapewnienia postulowanych wskaźników ekologiczno-przestrzennych. Beata Gawryszewska (architekt krajobrazu) i Tomasz Duda (psycholog środowiskowy) wzięli udział w zebraniu wspólnoty mieszkańców w czerwcu 2018 roku, aby wysłuchać uwag mieszkańców.

\section{Przykład budynków w osiedlu Kłobucka 14/16/18}

Osiedle domów komunalnych położone w sąsiedztwie toru treningowego kompleksu Wyścigów Konnych na Służewcu liczy dziewięć cztero- i siedmiokondygnacyjnych budynków wielorodzinnych rozrzuconych na powierzchni niespełna 2 ha. Zostało oddane do użytku w 2014 roku, po czterech latach trudnej inwestycji pełnej przestojów powodowanych niezdiagnozowanym wcześniej wysokim poziomem wód gruntowych (Kińczyk, 2014). W trakcie wizji lokalnej stało się jasne, że problem odwodnienia poziomu -1 budynku, a także zieleni na płytach stropowych garaży i komórek nadal nie jest rozwiązany. Rutynowo wprowadzone trawniki i pasy żywopłotów zamierają nad płytami garażowymi tak, że z dokładnością do centymetra można zlokalizować granice podziemnej zabudowy. Mieszkańcy deklarują chęć uprawiania ogrodów pod oknami, ale zdają sobie sprawę, że jest to niemożliwe. Projekt urbanistyczny osiedla (w 2018 r. dogęszczonego o kolejne budynki) maksymalnie wykorzystuje powierzchnię pod zabudowe, ale pozostawia niewiele powierzchni, które mogłyby być przeznaczone na przestrzenie wspólne. Jedyną taką przestrzenią jest teren placu zabaw niespełniający potrzeb mieszkańców w zakresie zarówno wielkości, jak i wyposażenia. Wzdłuż utwardzonych ciagów komunikacyjnych znajduja się pojedyncze młode drzewa. Poza wąskim pasem zieleni wzdłuż toru wyścigowego i zieleńca przy mikroskopijnym boisku nie ma również miejsca na swobodną wegetację roślin. W pobliżu, pomiędzy ul. Kłobucką a stacją Warszawa Okęcie znajduje się teren z ogródkami działkowymi i nieformalną zielenią.

\section{Przykład budynków w osiedlu Jagiellońska 47}

Osiedle położone na Golędzinowie, w sąsiedztwie Fortu Śliwickiego (Jasińskiego) Cytadeli Warszawskiej liczy dziewięć cztero- i siedmiokondygnacyjnych budynków wielorodzinnych. Osiedle o powierzchni 3,8 ha składa się dwóch części: starszej z 2012 roku i nowszej z 2015 roku. Nowsza część nawiązuje do „fortowej” przeszłości tego terenu swoją monolityczną zabudową z budynkami o elewacjami z czerwonej cegły (Springer, 2015). Obie części diametralnie się różnią pod względem dostępności do najbliższych terenów zieleni i możliwości „oddolnego” kształtowania ich struktury. W części z 2015 roku jest to niemożliwe, gdyż zastosowano tam duże powierzchnie nawierzchni nieprzepuszczalnych, które bezpośrednio graniczą z elewacjami budynków. W starszej części osiedla jest miejsce na ogródki podokienne i przestrzenie społeczne, a także na posadzenie drzew zapewniających właściwy wskaźnik pokrycia powierzchni rzuta- 
mi swoich koron, teren ze swobodną wegetacją czy zieleń na elewacjach. Na całym terenie jest zaledwie kilkanaście średniej wielkości drzew. $Z$ rozmów $\mathrm{Z}$ administratorem i kilkoma mieszkańcami wynika, że nie jest to dozwolone. $Z$ terenem sasiaduje obszerny teren nieformalnej zieleni miejskiej z dojrzałymi drzewami, ale jest to niestety teren inwestycyjny. Mieszkańcom pozostaje sąsiedztwo znajdujących się nieopodal otwartych terenów doliny Wisły.

Przeprowadzone obserwacje można podsumować następująco: w osiedlach są możliwości wprowadzenia postulowanej struktury zieleni z ogródkami mieszkańców, przestrzeniami społecznymi, ogrodami społecznościowymi oraz roślinnością na powierzchniach architektonicznych, ale wprowadzenie oczekiwanych wskaźników wymagałoby rozgęszczenia zabudowy i zastosowania zrównoważonych technologii. W szczególności dotyczy to zieleni na gruncie rodzimym i wskaźnika pokrycia koronami drzew, a także roślinności na powierzchniach architektonicznych. W obu przypadkach regulamin użytkowania mieszkań komunalnych uniemożliwia swobodną kreację ogrodów przez mieszkańców.

\section{ZALECENIA DOTYCZACE ZIELENI W WARSZAWSKIM STANDARDZIE MIESZKANIOWYM 1.2}

Opisane w rozdziałach 3-5 WSM 1.2 ustalenia pozwoliły na zweryfikowanie zapisów standardu w zakresie zieleni w rozdziale 3 „Przyroda”. Jego tekst w pełnym brzmieniu można znaleźć się na stronach Urzędu m.st Warszawy (BPL UM Warszawa, 2018). Pierwszą z regulacji są wartości przyrodnicze i kulturowe na terenie inwestycji. W standardzie czytamy: „Wartości przyrodnicze na terenie inwestycji należy rozpoznać, uwzględnić i utrwalić w koncepcji zagospodarowania terenu. Szczególną uwagę należy przywiązywać do starych drzew, obszarów (...) wartościowych (...) ze względu na np. (...) gatunki chronione czy siedliska o dużej różnorodności fauny i flory, (...) cieki wodne, (...) zagłębienia, gdzie tymczasowo zbierać może się woda deszczowa (...) Będą one docelowo stanowiły ważną część zagospodarowania terenu - tzw. EKOSPOT" (BPL UM Warszawa, 2018). Zapis ten odpowiada na obecne $\mathrm{w}$ certyfikacjach wskazania dotyczące ochrony wartości terenu inwestycji. Sa one obecne zarówno w systemie LEED, jak i BREEAM w rozdziałach poświęconych ocenie wartości ekologicznej terenu przeznaczonego pod zabudowę. Podobne zalecenia dotyczą istniejących historycznych układów zieleni, które powinny być zidentyfikowane i w miarę możliwości rewaloryzowane: „W przypad$\mathrm{ku}$, gdy na terenie inwestycji istniały zrealizowane wcześniej założenia urbanistyczno-krajobrazowe, np. parki, skwery, zieleń urządzona podwórek, należy przeprowadzić ich inwentaryzację i waloryzację oraz odrestaurować i zachować" (BPL UM Warszawa, 2018). Ten zapis odpowiada obecnej we wskaźnikach ekologiczno-przestrzennych ochronie drzew istniejacych, ale przede wszystkim docenia tradycję polskich osiedli mieszkaniowych drugiej połowy $\mathrm{XX}$ wieku, które przy rozmaitych niedostatkach standardu budynków cechowały się dobrze zaprojektowanymi kompozycjami zieleni.

Odpowiedzią na obecny w certyfikacjach LEED i BREEAM w rozdziałach dotyczących sposobu zagospodarowania terenu inwestycji postulat zachowania jak największej powierzchni gruntu rodzimego (Rozdziały: „Zrównoważony teren SS2 w LEED v4.1” oraz „Wykorzystanie terenu i ekologia LE02”; USGBC, 2019 oraz „Wartość ekologiczna terenu i ochrona cech ekologicznych w BREEAM NC"; BGL, 2016) jest koncepcja EKOSPOTu. „EKOSPOTem może być zarówno rozległy teren pokryty naturalną murawą, podszytem krzewów i koronami istniejących na jego terenie drzew, jak i niewielki obszar z pojedynczymi drzewami (...) Na terenie EKOSPOTu stosuje się wyłącznie rodzime gatunki roślin (...) jest aktywnym przyrodniczo miejscem pozostawionym swobodnej wegetacji, na gruncie rodzimym (nie na płycie garażowej), niepoddawanym zabiegom agrotechnicznym, ochronionym przed ingerencją w czasie prowadzenia prac inwestycyjnych, za wyjątkiem działań interwencyjnych (np. usunięcie złamanego, zagrażającego bezpieczeństwu konaru drzewa). EKOSPOT w miarę możliwości powinien zostać wydzielony z zieleni istniejącej, zachowanej na terenie inwestycji, jednak, gdy jej brakuje, może zostać założony $\mathrm{z}$ użyciem rodzimych gatunków roślin, najlepiej takich, które dają pożytek w postaci kwiatów i owoców drobnym zwierzętom. EKOSPOTy sąsiadujących 
inwestycji powinny się łączyć, co oznacza, że należy zadbać o ciągłość obszarów aktywnych przyrodniczo i ich połączenie z systemem lub innymi elementami struktury terenów przyrodniczych miasta" (BPL UM Warszawa, 2018). EKOSPOT „powinien stanowić co najmniej $40 \%$ powierzchni po odjęciu powierzchni ograniczonej obrysem zabudowy (nadziemnej i podziemnej) znajdującej się na terenie inwestycji. Teren inwestycji, po odjęciu powierzchni ograniczonej obrysem zabudowy powinien być pokryty w $25 \%$ rzutami koron drzew w obszarach mieszkaniowych w zabudowie miejskiej i w 50\% w obszarach mieszkaniowych w zabudowie podmiejskiej (wielkość tę należy uzyskać po 20 latach (...), dbając o zróżnicowany wiek populacji posadzonych drzew i krzewów" (BPL UM Warszawa, 2018). Ten ostatni wskaźnik będzie w naszym przekonaniu stymulować przemyślane projektowanie otoczenia budynków i je same. Możliwość produkcji własnych warzyw i owoców przez mieszkańców oraz wykorzystanie w kształtowaniu przestrzeni społecznych elementów jadalnego krajobrazu (np. drzew owocowych i ziół) jest jednym z postulatów certyfikatu WELL (Rozdział 3 ,WELL v02"; IWBI, 2019).

W podrozdziale „Ogrodowe przestrzenie społeczne" standardu znalazł się również zapis zabezpieczający oddolne kształtowanie się struktury ogrodowych domen terytorialnych $\mathrm{w}$ procesie zamieszkiwania: „Istotną część struktury zieleni, (...) stanowią ogródki podokienne zakładane i pielęgnowane przez mieszkańców. (...) mogą mieć również charakter społeczny lub być użytkowane przez sąsiadujące instytucje opiekuńcze, wychowawcze lub edukacyjne. W projekcie zagospodarowania terenu należy uwzględnić obszar przeznaczony na rozwój ogródków (...) w ciągu pierwszych kilku lat funkcjonowania inwestycji.". Dalej w tym samym miejscu czytamy: „Użytkownicy mają swobodę co do wyboru gatunków roślin do nasadzeń, z wyłączeniem drzew i gatunków inwazyjnych" (BPL UM Warszawa, 2018).

Tym sposobem standard powinien spowodować, że na terenie inwestycji, budowy lub remontu budynku w zasadzie nie będzie anonimowej „zieleni miejskiej”. Przewiduje się jednak, że w początkowym okresie, zanim mieszkańcy przejmą odpowiedzialność za przestrzeń wokół budynku i założą ogrody, zainicjowanie nasadzeń w miejscach nieobjętych EKOSPOTem będzie konieczne. I tu autorzy oparli się na ustaleniach dotyczących zmiany preferencji estetycznych mieszkańców Warszawy w zakresie zieleni (Gawryszewska i in., 2018). W tekście standardu znalazł się bowiem zapis wskazujący na akceptacje estetyki swobodnej wegetacji w zagospodarowaniu „zielonej” części inwestycji: „Zieleń urządzona poza EKOSPOTem powinna budować różnorodność biologiczną obszaru. Na etapie projektowania należy zapewnić zróżnicowanie gatunków, zgodność z zastanymi warunkami oraz utrzymanie roślin na różnych wysokościach docelowych (traw, bylin, krzewów i drzew). (...) Należy stosować drzewa i krzewy rodzime, stosownie do warunków siedliskowych zastanych na terenie (przykładowe drzewa: sosny pospolite, modrzewie europejskie, dęby szypułkowe i bezszypułkowe, brzozy pospolite, graby pospolite, rodzime lipy i klony etc.; przykładowe krzewy: derenie jadalne, ałycza, kaliny koralowe, róża psia, bez czarny i koralowy, ligustr pospolity etc.). (...) Murawy koszone powinny zawierać zarówno gatunki jednoliścienne jak i dwuliścienne, np. bobowate" (BPL UM Warszawa, 2018).

Zapisy te są dodatkowo poparte wskazaniem sugerowanych zrównoważonych technologii mających na celu ochronę różnorodności biologicznej i zapewnienie małej retencji na terenie inwestycji, co również jest postulowane we wskaźnikach ekologiczno-przestrzennych przy okazji wymagań związanych z zarządzaniem wodą deszczową. Standard stanowi, że „należy unikać stosowania tkanin technicznych na rzecz ściółkowania. (...) Ciagi komunikacyjne powinny być pokryte jedynie niezbędnymi utwardzeniami.". „Ogródki przydomowe, społeczne i pozostała zieleń osiedlowa powinny być nawadniane wodą deszczową lub wodą szarą - pochodzącą z recyklingu.”. „Na terenie inwestycji należy stosować nawierzchnie wodoprzepuszczalne, a w miarę możliwości wprowadzić zbiorniki wodne, instalacje wody szarej itp., umożliwiające małą retencję i recykling wody.”. Zrównoważone technologie stanowią $\mathrm{w}$ tekście standardu wstęp do problematyki związanej ze wskaźnikiem ekologiczno-przestrzennym. Standard podaje próbę sformułowania takiego wskaźnika z wykorzystaniem Seattle Green Factor (2007), w którym szczególnie 
premiowane jest zachowanie istniejącej roślinności, kultywowanie ogrodów mieszkańców, stosowanie wysokich nasadzeń gatunków rodzimych, a także zastosowanie nawierzchni wodoprzepuszczalnych (BPL UM Warszawa, 2018).

Ostatnią grupą zapisów standardu są te, które dotyczą zieleni na powierzchniach architektonicznych: „Ściany i inne elementy pionowe, a także dachy i zadaszenia, powinny być w miarę możliwości pokryte zielenią, zapewniając jak największą powierzchnię choćby w minimalnym stopniu aktywną biologicznie. (...) Ukształtowanie elewacji w rejonie okien i balkonów powinno umożliwiać uprawę co najmniej roślin sezonowych (...) Przy wyborze technologii pierwszeństwo przed systemami zieleni wertykalnej mają pnącza zakorzenione $\mathrm{w}$ gruncie, a przed technologiami dachów ekstensywnych, o ile to tylko możliwe - dachy intensywne. Budynki gospodarcze, wiaty i altany (w tym śmietnikowe) powinny być zazielenione $\mathrm{z}$ wykorzystaniem jak najprostszych technik i technologii. Oprócz technologii zielonych dachów należy wykorzystywać systemy trejaży i pergoli dla zazieleniania ścian i pokryć dachowych" (BPL UM Warszawa, 2018)

\section{WNIOSKI}

W preambule rozdziału 3 WSM 1.2 czytamy: „Bliska relacja $\mathrm{z}$ przyrodą i krajobrazem jest niezbędnym elementem przyjaznego zamieszkiwania. Nie tylko bezpośrednio przyczynia się do poprawy jakości środowiska codziennego życia, ale i przeciwdziała stresowi, agresji i innym zrachowaniom społecznie niepożądanym (Kaplan, 1995). (...) Codzienny kontakt $\mathrm{z}$ roślinami, zwierzętami i innymi żywymi organizmami umożliwia edukację najmłodszych pokoleń, ukazując przynależność człowieka do świata natury. Postrzegane $\mathrm{w}$ ten sposób środowisko przyrodnicze stanowi podstawę, a nie uzupełnienie inwestycji. Należy uznać, że inwestycja jest lokalizowana, realizowana i eksploatowana w przyrodzie, a nie odwrotnie. (...) Tworząc krajobraz miasta, będący rezerwuarem różnorodności biologicznej i kształtując mikroklimat (poprzez oczyszczanie powietrza $\mathrm{z}$ dwutlenku węgla, wytwarzanie tlenu, obniżanie temperatury $\mathrm{w}$ wyniku parowania, oczyszczanie powietrza $\mathrm{z}$ cząstek pyłu) są nie do zastapienia (Szczepanowska, 2001). (...) Właściwe funkcjonowanie krajobrazu miasta jako podstawy zamieszkiwania wymaga ciagłości zielonej infrastruktury (Komisja Europejska, 2013). Bezpośrednie sąsiedztwo połączonych w system terenów zieleni podwórek, parków osiedlowych i miejskich, parków i ogrodów historycznych stanowiących zarazem dziedzictwo kulturowe miasta, a także miejskich obszarów leśnych i terenów otwartych buduje jakość mieszkania w Warszawie. Dlatego należy za wszelką cenę przeciwdziałać jego fragmentacji przez nowe inwestycje." (BPL UM Warszawa, 2018).

Przedstawione zapisy WSM 1.2 wychodzą naprzeciw zarówno oczekiwaniom mieszkańców wyrażonym w tradycji oddolnego kształtowania najbliższego otoczenia miejsca zamieszkania, jak i certyfikatom funkcjonującym w międzynarodowej praktyce inwestycji mieszkaniowych. Metoda pracy polegająca na ich weryfikacji w dyskusji potwierdziła zasadność tych zapisów. Należy jednak zwrócić uwage, że WSM 1.2 nie zabezpiecza postulowanych $\mathrm{w}$ preambule interesów zielonej infrastruktury. Jego słabościa jest również nieuwzględnienie lub uwzględnienie niejako „między wierszami" urbanistyki osiedli mieszkaniowych i szeroko rozumianego planowania terenów zieleni miejskiej - jest to bowiem standard dla budynków, nie osiedli, dlatego praca nad nim powinna być w tym kierunku kontynuowana.

Kolejną słabością powstającego dokumentu jest jego zastosowanie wyłącznie do inwestycji miejskich, choć założenie, że to właśnie budynki stanowiące majątek komunalny mają być inwestycjami o najlepszym standardzie i najwyższej jakości, nie jest pozbawione logiki. Jeśli jednak myśleć o znaczeniu warszawskiego standardu w szerszej skali, powinien on przekształcić się w certyfikację, co wymaga opracowania i zweryfikowania w praktyce przywołanych w tekście WSM 1.2 wskaźników.

Poza tymi słabymi stronami WSM 1.2 ma również mocną. Jest nią koncepcja EKOSPOTu i towarzyszące jej zasady wyboru roślin rodzimych i ekstensywnego zagospodarowania przestrzeni niewchodzących w strukturę ogrodów prywatnych i społecznych. Ta nowatorska koncepcja zieleni osiedlowej oparta na wynikach badań struktury zieleni i procesu zamieszkiwania daje szansę na rewitalizację obszarów 
zamieszkiwanych w jej pełnym znaczeniu - społecznym (ze względu na stymulowanie postaw kreatywnych), ekonomicznym (ze względu na redukcję kosztów utrzymania zieleni) i przestrzennym poprzez kształtowanie współczesnego krajobrazu miasta zgodnego z oczekiwaniami jego mieszkańców.

\section{Podziękowania}

Jesteśmy wdzięczne pracownikom Biura Polityki Lokalowej Urzędu m.st. Warszawy, w szczególności dyrektorowi biura Grzegorzowi Okońskiemu, za stworzenie możliwości przygotowania tego dokumentu oraz administracyjne i logistyczne wsparcie przy jego powstawaniu.

Dziękujemy współautorom i opiekunom merytorycznym ze strony Urzędu m.st. Warszawy, w szczególności: Joannie Erbel (Biuro Polityki Lokalowej Urzędu m.st. Warszawy), Sławomirowi Sendzielskiemu i Mirosławowi Gajdakowi (Zarząd Zieleni m.st. Warszawy).

Podziękowania składamy również zespołowi recenzentów i konsultantów za uwagi i komentarze do wersji 1.1 standardu: dr hab. inż. arch. kraj. Barbarze Szulczewskiej - prof. SGGW, dr inż. arch. kraj. Renacie Giedych, dr. Krzysztofowi Herbstowi, dr. inż. Jerzemu Kwiatkowskiemu, dr. inż. arch. kraj. Markowi Piwowarskiemu, dr inż. arch. Katarzynie Sadowy.

\section{PIŚMIENNICTWO}

Biernacka, J. (2016). Lokalne społeczności przyjazne dla klimatu. Inkubator Mieszkania 2030. W Materiały debaty „Mieszkania przyjazne dla klimatu”, 25.01.2017 Warszawa. Pobrano z lokalizacji: http://2030.um.warszawa.pl/mieszkania2030-biernacka-lokalne-spolecznosci-przyjazne-dla-klimatu [dostęp 3.05.2019].

Biuro Polityki Lokalowej Urzędu m.st. Warszawy [BPL UM Warszawa] (2018). Warszawski Standard Mieszkaniowy 1.2 (projekt do konsultacji). Warszawa. Pobrano z lokalizacji: http://konsultacje.um.warszawa.pl/sites/konsultacje.um.warszawa.pl/files/1_warsz_standard_mieszkaniowy_do_konsultacji.pdf [dostęp 3.05.2019].

BRE Global (2016). BREEAM. International New Construction. Technical Manual SD233 2.0. Watford. Pobrano z lokalizacji: https://www.breeam.com/BREEAMInt2016SchemeDocument/content/resources/output/10 pdf/a4_pdf/nc_pdf_printing/sd233_nc_int_2016_print. pdf [dostęp 3.07.2017].
Brukalska, B. (1947). Zasady społeczne projektowania osiedli mieszkaniowych. Warszawa: Trzaska, Evert i Michalski.

Del Tredici, P. (2014). The Flora of the Future. Pobrano z lokalizacji: https://placesjournal.org/article/the-floraof-the-future [dostęp 30.12.2016].

English Nature (2014). Accessible Natural Greenspace Standard. Pobrano z lokalizacji: https://webarchive. nationalarchives.gov.uk/20140605111422/http://www. naturalengland.org.uk/regions/east_of_england/ourwork/gi/accessiblenaturalgreenspacestandardangst.aspx [dostęp 3.05.2019].

Gawryszewska, B. J. (2013). Ogród jako miejsce w krajobrazie zamieszkiwanym. Warszawa: Wieś Jutra.

Gawryszewska, B. J. (2018). Zielona zmiana w krajobrazie miasta. Wernakularne ogrody miejskie jako konsekwencja przemian wizerunku, funkcji i znaczenia zieleni w przestrzeni publicznej. Societas Communitas, 2 (26), 121-142.

Gawryszewska, B. J. i Piłko, A. (2004). The social space analysis based on greenery inven-tory in Warsaw public housing development WSM Żoliborz. Annals of Warsaw Agricultural University. Horticulture (Landscape Architecture), 25, 113-119.

Gawryszewska, B. J. i Wilczyńska, A. (2016). Creative urban areas or urban gardening as a process of contemporary cityscape making. W J. Słyk i L. Bezerra (red.), Architecture for the Society of Knowledge. Tom 1: Education for research, research for creativity (strony 248-253). Warszawa: Wydział Architektury Politechniki Warszawskiej.

Gawryszewska, B. J., Ciszewska, M., Łepkowski, M., Nejman, R. i Wilczyńska, A. (2018). The recreational potential of wastelands as well as users' preferences for wasteland aesthetics. E3S Web of Conferences, 45, \#00018. https://doi.org/10.1051/e3sconf/20184500018

Gawryszewska, B. J., Łepkowski, M. i Wilczyńska, A. (2019). City wastelands. Creating spaces of vernacular democracy. W C. Certoma, M. Sondermann i S. Noori (red.), Urban gardening and the struggle for social and spatial justice (strony 38-58). Manchester: Manchester University Press.

Giedych, R. (2015). Wskaźniki ekologiczno-przestrzenne jako standard kształtowania zabudowy mieszkaniowej. W B. Szulczewska (red.), Osiedle mieszkaniowe w strukturze przyrodniczej miasta (strony 46-58). Warszawa: Wydawnictwo SGGW.

International WELL Building Institute [IWBI] (2019). WELL v2. The next version of the WELL Building Standard, Q2 2019. New York. Pobrano z lokalizacji: https://v2.wellcertified.com/v2.4/en/concepts [dostęp 3.05.2019]. 
Kaplan, S. (1995). The restorative benefits of nature: Toward an integrated framework. Journal Of Environmental Psychology, 15, 69-182

Kińczyk, S. (2014). Kilka rodzin już mieszka... Kłobucka-szczęśliwy finat koszmarnej inwestycji?, Pobrano z lokalizacji: https://www.haloursynow.pl/artykuly/kilka-rodzin-juz-mieszka-klobucka-szczesliwy-final-koszmarnej-inwestycji,3086.htm [dostęp 3.05.2019].

Koło Naukowe Wydziału Architektury Wnętrz ASP w Warszawie [Koło Naukowe WAW ASP] (1941). Karta Ateńska: urbanistyka C.I.A.M. 1933. Warszawa.

Komisja Europejska (2013). Komunikat Komisji do Parlamentu Europejskiego, Rady, Europejskiego Komitetu Ekonomiczno-Społecznego i Komitetu Regionów. Zielona infrastruktura - zwiększanie kapitału naturalnego Europy. COM(2013) 249 final. 06.05.2013 Bruksela.

Kowarik, I. (2011). Novel urban ecosystems, biodiversity and conservation. Environmental Pollution, 159, 1974$-1983$.

Lewicka, M. (2012). Psychologia miejsca. Warszawa: Scholar.

Maco, S. E. i McPherson, E. G. (1999). Canopy Cover in Street Tree Populations of tree cover on parking lot microclimate and vehicle emissions. Arboric, 25 (3), 129-142.

Springer, F. (2015). Na warszawskiej Pradze stanęty budynki komunalne, które zaskakuja standardem $i$ wygladem. Pobrano z lokalizacji: http://weekend.gazeta. pl/weekend/1,152121,17489388,Na_warszawskiej_ Pradze_stanely_budynki_komunalne_html [dostęp 3.05.2019].

Szczepanowska, H. B. (2001). Drzewa w mieście. Warszawa: Hortpress.

Szulczewska, B., Giedych, R. i Solarek, K. (2015). Problemy stosowania wskaźnika terenów biologicznie czynnych na tle wyników badań - podsumowanie. W B. Szulczewska (red.), Osiedle mieszkaniowe w strukturze przyrodniczej miasta (strony 141-148). Warszawa: Wydawnictwo SGGW.

U.S. Green Building Council [USGBC] (2019). LEED v4.1. Residential BD+C Multifamily Homes Core and Shell. Washington, DC. Pobrano z lokalizacji: https://new. usgbc.org/leed-v41\#residential [dostęp 3.05.2019].

Wilson, E. O. (2009). Biophilia. Cambridge MA: Harvard University Press.

\section{GREENERY IN WARSAW HOUSING STANDARD}

\section{ABSTRACT}

Warsaw Housing Standard version 1.2 (Warszawski Standard Mieszkaniowy - WSM 1.2) developed in 2018 by the City Council of Warsaw lists a nature, and a greenery as one of five priorities in urban investments. That is why it was so important to develop it using principles of the sustainable construction, including the needs of the residents' community. The aim of the article was to verify the standard's regulations on the background of processes of dwelling, as well as the changing aesthetic preferences of residents in the field of greenery and popular building and sustainable technology standards. The paper contains extensive quotations of WSM 1.2 and a comparison of indicators and research results. The material aimed characteristics of contemporary directions in landscaping in residential areas and its optimization (including free vegetation and residents' grass-roots initiatives). The concept of EKOSPOT has also been widely discussed.

Key words: green indexes, social space, residential area, urban renewal, council housing, EKOSPOT 